\title{
Resternotomy in children with congenital heart disease - management algorithm applied in the Department of Cardiothoracic Surgery in Children's Memorial Health Institute in Warsaw
}

\author{
Radoslaw Jaworski, Andrzej Kansy, Mariusz Birbach, Andrzej Pastuszko, Krzysztof Mozol, Michal Kozlowski, \\ Aleksandra Wasiak, Piotr Burczynski, Bohdan Maruszewski
}

Department of Cardiothoracic Surgery, Children's Memorial Health Institute, Warsaw, Poland

Kardiochir Torakochir Pol 2019; 16 (4): 201-205

\begin{abstract}
The paper summarizes key problems related to resternotomy in children with congenital heart defects which were discussed during the $9^{\text {th }}$ Congress of the Polish Society of Cardiothoracic Surgeons 2018 in Szczecin. An attempt was made to address various aspects of the issue in order to systematize the available knowledge and minimize the risks associated with reoperations in this particular group of patients. Additionally, the paper presents the algorithm for diagnostic and therapeutic management applied in children considered eligible for resternotomy in the Department of Cardiothoracic Surgery in Children's Memorial Health Institute in Warsaw.
\end{abstract}

Key words: resternotomy, reoperation, pediatric cardiac surgery, congenital heart defects.

\section{Introduction}

On 21-23 June 2018, the $9^{\text {th }}$ Congress of the Polish Society of Cardiothoracic Surgeons 2018 was held in Szczecin [1]. Among many topics addressed during the event was a session devoted to reoperations in children with previous surgery for congenital heart defects, with a special emphasis on resternotomy. Below is a summary of the issues discussed, which is an attempt to systematize the available knowledge of difficult aspects involved in reoperations and resternotomy in children with congenital heart defects. Also, we present the algorithm for diagnostic and therapeutic management applied in children considered eligible for resternotomy in the Department of Cardiothoracic Surgery in Children's Memorial Health Institute in Warsaw.

For the purpose of this study, reoperation was defined as any type of operative procedure that requires surgical intervention within the tissues and cavities of the body that were previously operated on. Also, the authors of the study defined resternotomy as any type of operative pro-

\section{Streszczenie}

W artykule podsumowano zagadnienia dotyczące resternotomii u dzieci z wrodzonymi wadami serca poruszane na IX Kongresie Polskiego Towarzystwa Kardio-Torakochirurgów 2018 w Szczecinie. Podjęto próbę omówienia różnych aspektów tego zagadnienia, która ma na celu usystematyzowanie dostępnej wiedzy oraz zminimalizowanie ryzyka związanego z ponownymi operacjami w tej grupie pacjentów. Dodatkowo przedstawiono algorytm postępowania diagnostyczno-leczniczego u dzieci zakwalifikowanych do resternotomii stosowany w Klinice Kardiochirurgii Instytutu - Pomnik Centrum Zdrowia Dziecka w Warszawie.

Słowa kluczowe: resternotomia, ponowna operacja, kardiochirurgia dziecięca, wrodzone wady serca.

cedure in which the sternum must be cut through in order to gain access to the mediastinum. In the English-language literature, the adopted definition corresponds to the term "reoperative sternotomy".

\section{Scale of the problem}

According to data from the Polish Register of Cardiac Surgery (KROK) and the ECHSA database, more than 500 reoperations in children a year have been performed in Poland in recent years, which accounts for approximately $20 \%$ of all cardiac surgeries in this patient group [2]. According to the American Society of Thoracic Surgeons Congenital Heart Surgery Database (STS-CHSD), the number of reoperations over a 5-year follow-up period was 30,673, which accounted for $33 \%$ of all cardiac surgical procedures performed in patients with congenital heart defects [3]. Constant advances in medicine and data from the registers suggest that this number will rise in the coming years. It must also be noted that an increasing number of children

Address for correspondence: Radoslaw Jaworski MD, PhD, Department of Cardiothoracic Surgery, Children's Memorial Health Institute, Warsaw, Poland, phone: +48 2281573 46, e-mail: radicis@go2.pl

Received: 12.08.2019, accepted: 17.11.2019. 
undergoing cardiac surgery due to congenital heart defects reach adulthood and will represent a significant group of patients eligible for subsequent cardiac surgery in adult healthcare centers [4].

Resternomy, or the reopening of the sternum, is associated with an increased risk of perioperative complications and elevated mortality rates. Unfortunately, there are few publications addressing this issue, and the available literature focuses mainly on adult patients [4]. Launcelott et al. report that the risk of in-hospital mortality associated with repeat cardiac surgery among adult patients is three times higher than in patients undergoing surgery for the first time [5]. The authors note that the risk factors in the group of patients described above include the number of reoperations greater than 2. Follis et al. point out that the risk of massive hemorrhage during resternotomy is approximately $1 \%$, and the associated mortality is as high as $21 \%$ [6].

Naturally, accurate planning of resternotomy and appropriate operative techniques may improve the safety of the procedure, but the perioperative risk is always higher than during the initial sternotomy. Consequently, it is very important to take preventive measures during the initial sternotomy, especially in patients who are expected to require resternotomy at a later date. One of the measures potentially reducing the risk of complications during resternotomy is closure of the pericardium at the original operation. However, there is no consensus on this practice among surgeons [4]. Available options include complete and partial closure of the pericardium, pericardial closure using implantable materials, or leaving the pericardium open. An argument against pericardial closure is the possibility of postoperative hemodynamic instability because of the limited space housing the heart, especially in view of cardiac edema developing after prolonged extracorporeal circulation (ECC). However, it should be stressed that, where possible, measures are recommended to prevent the formation of adhesions between the epicardial surface and the great vessels, and the posterior surface of the sternum. In this manner, the risk of injury during resternotomy can be decreased [7]. The measures referred to above include pericardial closure, the use of membranes, and the application of agents reducing the formation of adhesions. At the same time, it must be highlighted that an increased formation of mediastinal adhesions is seen after the implantation of foreign materials, particularly of biological origin.

\section{Planning of resternotomy}

The first stage of resternotomy planning involves preoperative imaging evaluation to determine, among other aspects, the position of the great vessels and the heart in relation to one another and to the bone structures. Stainless steel sternal sutures left during the previous operation are a useful aid, providing an excellent point of reference both in the assessment of angiograms in the anteroposterior (AP) and lateral views. Critical information on the mutual spatial relations between the great vessels and the heart and the posterior surface of the sternum can be obtained by computed tomography with contrast (CT angiography CTA), while magnetic resonance imaging (MRI) is of lesser importance in this application. The spatial relations referred to above can also be assessed to a certain extent on the basis of images obtained during cardiac catheterizations. It is estimated that introducing the principle of preoperative CT examination leads to the modification of operative strategy in $20 \%$ of patients undergoing repeat cardiac surgery. Khan et al. report an even higher percentage, up to $80 \%$ [8-10]. Also, the application of visualization and 3D printing technology in patient preparation for resternotomy has been reported [11]. It appears that at least one imaging assessment should be performed before resternotomy to evaluate the position of the heart and great vessels relative to the posterior wall of the sternum. It may be an important aspect of patient preparation for resternotomy. In the Department of Cardiothoracic Surgery, Children's Memorial Health Institute in Warsaw, the most commonly performed examination evaluating the relative positions of thoracic organs and the posterior sternum is $\mathrm{CT}$ angiography of the chest.

Another aspect contributing to appropriate patient preparation for resternotomy is the evaluation of femoral and iliac arteries and veins or, in specific cases, extrathoracic vessels. In this way, it is possible to plan arterial and venous cannulation sites for connecting the extracorporeal circulation. A limited and approximate assessment can be performed by determining the presence of scars in the inguinal region after any previous interventions, and examining the pulse over the femoral arteries. Preoperative angiography is another method which can provide crucial information for the surgeon. An accurate and reliable assessment of the femoral vessels can be obtained by Doppler ultrasound. The technique is useful primarily for determining vascular patency. Consequently, before scheduled resternotomy, especially if the patient has a history of femoral vascular procedures, it is important to determine the patency of these vessels by Doppler ultrasound.

When planning a reoperation, it is also necessary to collect relevant information by consulting the records of previous surgical interventions, including anatomically atypical positions of thoracic structures, scope and techniques of surgical interventions applied, and materials used (biological grafts and synthetic materials, pericardial membranes, etc.). Experts highlight that from the $3^{\text {rd }}$ week after sternotomy adhesions are very highly vascularized, with a tendency to bleed, after which they organize into solid hard structures. A point to note is that according to authors from the Mayo Clinic, reoperation performed within 6-12 months after the initial surgery entails a higher risk of complications, and the release of mediastinal adhesions is more difficult during this period [4].

\section{Resternotomy}

It seems clear that before reopening the chest by sternotomy, the patient's groins should be prepared for possible femoral cannulation (alternatively, other peripheral 
vessels can be considered for cannulation). The extent of preparation of the groins depends on the operating surgeon and the experience of the healthcare center, and may consist of the following stages: 1) preoperative evaluation to determine the location of femoral vessels, 2) preparation of the groins for exposure (hair shaving immediately before surgical field cleaning), 3) cleaning and draping of the surgical field, 4) exposure of femoral vessels and intraoperative evaluation of possibilities for their cannulation, 5) arterial cannulation, and 6) venous cannulation. The minimum scope of preparation should comprise stages 1 to 3. The decision to implement other stages is at the discretion of the operating surgeon, though in certain situations it is advised to heparinize the pediatric patient before opening the chest to reduce the time needed to connect and start extracorporeal circulation (ECC) in the event of a sudden hemorrhage. Importantly, the use of ECC prior to resternotomy is associated with a longer duration of ECC, and hence an increased risk of postoperative hemorrhage, though it reduces the risk of tissue injury during resternotomy, as well as decreases the risk of organ hypoperfusion and improves myocardial protection, especially if cardiac and vascular structures are adversely affected by massive hemorrhaging [7]. If injury to the right side of the heart occurs during resternotomy, actions to be taken include femoral artery cannulation and blood draining from the site of injury into the ECC until injuries to the cardiovascular structures have been managed [12]. One of the most severe injuries that may occur during resternotomy is aortic injury. In such situations, even immediate initiation of the ECC may be inadequate to ensure the required degree of safety to the patient. Cardiac defects associated with an elevated risk of aortic damage during resternotomy procedures include, for example, transposition of the great arteries [12]. If preoperative imaging reveals close proximity of the aorta and/or pulmonary arteries to the posterior sternal surface - especially in cases when the mobility of these structures in relation to one another is not shown by angiographic imaging - there is a high probability of their fusion, which entails an increased risk of their injury during resternotomy. Where this is the case, femoral cannulation, both arterial and venous, should be considered even prior to commencing resternotomy. Some authors propose that in such situations ECC support and patient cooling should be initiated already before resternotomy [12]. In critical situations, immediate cooling of the patient and reduction of cardiac output should be considered, so that injury management can be undertaken. In cases of femoral vein cannulation, care should be taken to ensure that the cannula is placed at the level of the right atrium in order that the right side of the heart can be decompressed (also using vacuumassisted venous drainage - VAVD), which may reduce the risk of injury to these structures during resternotomy. It must be stressed that VAVD should be used with extreme caution in patients with an intracardiac connection between the right and left sides of the heart. In view of the risk of air embolism, some medical centers advise against this technique in the patient group under consideration [4]. Apart from the femoral vessels, other peripheral cannulation sites can be considered (e.g. iliac, axillary and cervical vessels), however they are rarely used. If access is gained to convenient cannulation sites in the chest, a change in arterial and venous cannulation from cannulated femoral vessels should be considered, if applicable. The advantages and disadvantages of the selected ECC method should always be considered on a case-by-case basis, taking into account the duration of possible ischemia of the lower limb where the femoral vessels have been cannulated. Potential complications associated with peripheral vascular cannulation include wound-related complications, limb ischemia, pseudoaneurysm, formation of hematomas, nerve plexus injury, and lymphorrhea [7].

\section{Additional notes}

There are a number of additional techniques that prove very useful during resternotomy, such as intraoperative blood-salvage devices (so-called cell savers), sticking defibrillation electrodes to the skin surface before draping the surgical field, and the application of carbon dioxide in the surgical field. The proposed management algorithm applied in patients undergoing resternotomy in the Department of Cardiothoracic Surgery, Children's Memorial Health Institute in Warsaw, is shown in Figure 1. Selected problems occurring in patients prepared for resternotomy together with proposed actions are listed in Table I.

\section{One of resternotomy techniques employed in the Department of Cardiothoracic Surgery, Children's Memorial Health Institute in Warsaw}

Prior to draping the surgical field, the routine procedure is to stick defibrillation electrodes to the skin. The scar af ter previous sternotomy can be excised. The wire stitches are cut, but not removed, as they are perfect landmarks and limit the depth of penetration of an oscillating saw while cutting through the sternum, and thus protect the structures in close proximity underneath. Dissection usually starts from the inferior sternum with the division of the xiphoid process and the linea alba. In this manner, access is gained to the posterior part of the sternum. The sternum is cut gradually from the bottom upwards, using coagulation, an oscillating saw and/or surgical shears, to expose the posterior sternal surface. To facilitate the dissection, the edges of the sternum are elevated with hooks or, alternatively, thick sutures are placed on both sides of the sternum. When cutting the sternum, care must be taken to gradually release substernal adhesions to gain access to the pleural spaces. In this way, the insertion of the sternal retractor is facilitated, and the tension between the adhesions and the heart chambers is reduced, lowering the risk of accidental tissue tears. In larger-sized patients, who are exposed to a very high risk during resternotomy, it may be technically easier to perform a small anterolateral thoracotomy on the right side prior to resternotomy. The maneu- 
Resternotomy in children with congenital heart disease - management algorithm applied in the Department of Cardiothoracic Surgery in Children's Memorial Health Institute in Warsaw

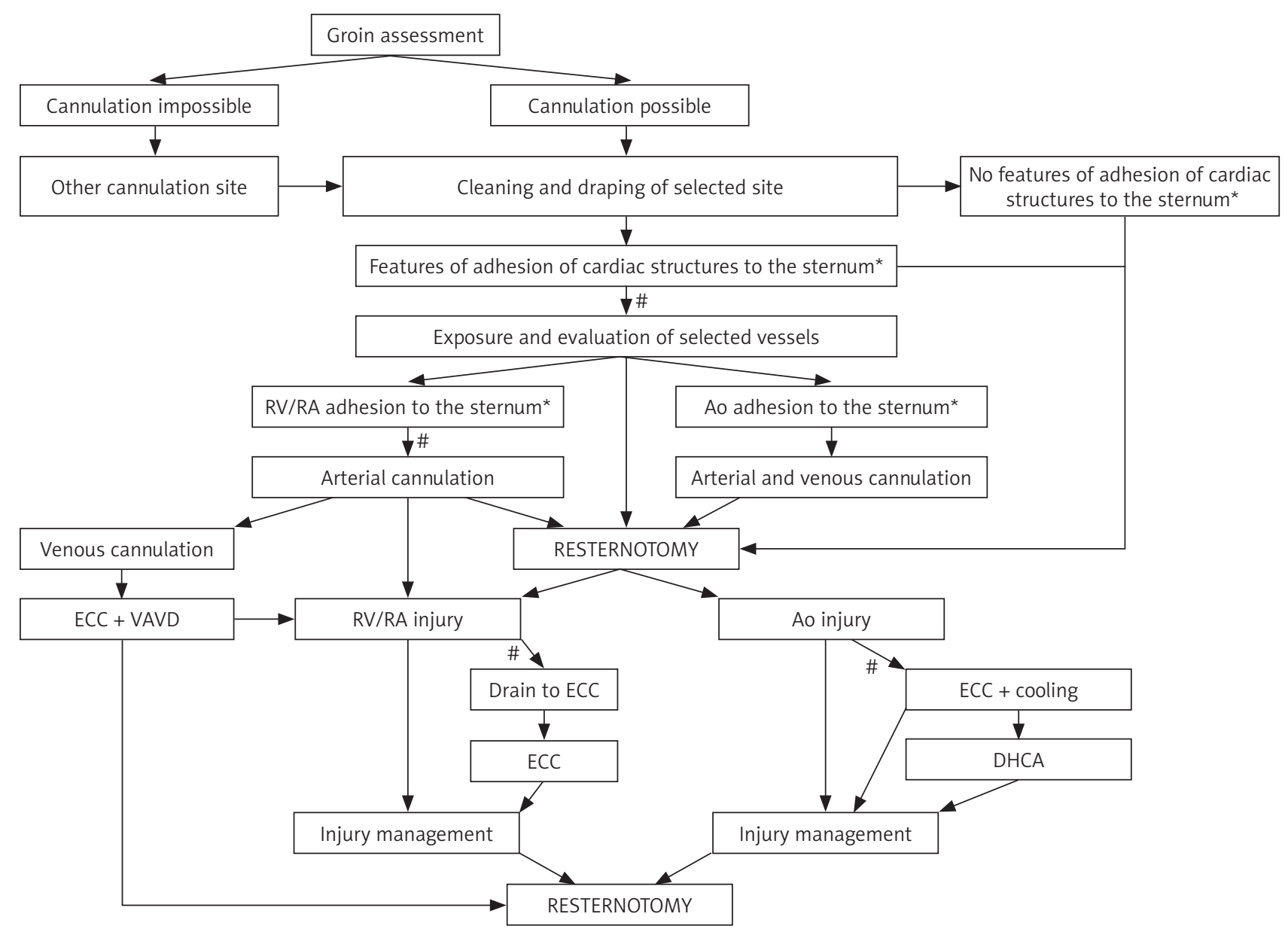

Figure 1. Management algorithm applied in the Department of Cardiothoracic Surgery, Children's Memorial Health Institute in Warsaw, in patients undergoing resternotomy

*Assessment based on preoperative imaging examinations (e.g. CTA), Ao - aorta, RV - right ventricle, RA - right atrium, ECC - extracorporeal circulation, DHCA - deep hypothermic circulatory arrest, VAVD - vacuum assisted venous drainage, " possible times for heparin administration.

Table I. The most common problems encountered during resternotomy and the proposed management algorithm

\begin{tabular}{|c|c|}
\hline Problem & Management \\
\hline $\begin{array}{l}\text { Evaluation of the position of the great vessels and } \\
\text { heart relative to the sternum }\end{array}$ & CTA of the chest, angiography, MRI \\
\hline Evaluation of femoral and iliac vessels & Angiography, Doppler ultrasound \\
\hline No possibility of femoral vessel cannulation & Consideration of other possible peripheral cannulation sites \\
\hline Features of RV adhesion to the sternum & $\begin{array}{l}\text { Groin preparation, exposure and evaluation of blood vessels in the groin, possibly } \\
\text { arterial cannulation, possibly venous cannulation, possibly initiation of ECC + VAVD } \\
\text { to decompress the heart }\end{array}$ \\
\hline RV/RA injury & Arterial cannulation + drain to the ECC, ECC, management of injury \\
\hline Features of aortic adhesion to the sternum & $\begin{array}{l}\text { Groin preparation, exposure and evaluation of blood vessels in the groin, possibly } \\
\text { arterial cannulation, possibly venous cannulation, possibly initiation of ECC + } \\
\text { patient cooling }\end{array}$ \\
\hline Aortic damage & ECC, possibly patient cooling, possibly DHCA, management of injury \\
\hline Significant femoral vascular stenosis after cannulation & Angioplasty (e.g. using a patch from the patient's own pericardium) \\
\hline
\end{tabular}

ver allows the structures attached to the posterior surface of the sternum to be dissected away, which is followed by sternotomy controlled by the operating surgeon's hand placed behind the sternum [8].
Once the sternum is open, dissection can be initiated in the area between the diaphragm and the cardiac surface. Typically, the location is characterized by the smallest number of adhesions, which facilitates the identification of 
appropriate layers. The dissection is performed using coagulation or scissors. Where possible, the sites of venous and arterial cannulation should be made accessible first, after which dissection should be continued to the required extent.

\section{Conclusions}

Resternomy, or the reopening of the sternum, is associated with an increased risk of perioperative complications and elevated mortality rates. With the progress in cardiac surgical treatment of children and young adults, the number of patients who need subsequent surgery is growing. Appropriate patient preparation for resternotomy is an aspect of paramount importance. Preoperative management involves evaluation of the position of the great vessels and the heart in relation to one another and to the bone structures, assessment of patency of peripheral vessels to determine the possibility of cannulation, and collection of relevant information from the records of previous surgical interventions (such as anatomically atypical positions of thoracic structures, scope of surgery and operative techniques applied, and implantable materials used). A number of resternotomy techniques are applied, which differ depending on the experience of the treatment center and surgeons performing the procedure. It appears that accurate planning of resternotomy and appropriate operative techniques may increase the safety of the procedure, but the perioperative risk is always higher than during the primary sternotomy.

The paper has been inspired by the presentations and discussion held during the session on resternotomy in children at the $9^{\text {th }}$ Congress of the Polish Society of Cardiothoracic Surgeons 2018 in Szczecin, on 21-23 June 2018.

\section{Disclosure}

The authors report no conflict of interest.

\section{References}

1. https://www.termedia.pl/Konferencje?Intro\&e $=830 \& p=5043$.

2. http://www.krok.org.pl.

3. Jacobs JP, Mavroudis C, Quintessenza JA, Chai PJ, Pasquali SK, Hill KD, Vricella LA, Jacobs ML, Dearani JA, Cameron D. Reoperations for pediatric and congenital heart disease: an analysis of the Society of Thoracic Surgeons (STS) congenital heart surgery database. Semin Thorac Cardiovasc Surg Pediatr Card Surg Annu 2014; 17: 2-8.

4. Said SM, Dearani JA. Strategies for high-risk reoperations in congenital heart disease. Semin Thorac Cardiovasc Surg Pediatr Card Surg Annu 2014; 17: 9-21.

5. Launcelott S, Ouzounian M, Buth KJ, Légaré JF. Predicting in-hospital mortality after redo cardiac operations: development of a preoperative scorecard. Ann Thorac Surg 2012; 94: 778-784.

6. Follis FM, Pett SB Jr, Miller KB, Wong RS, Temes RT, Wernly JA. Catastrophic hemorrhage on sternal reentry: still a dreaded complication? Ann Thorac Surg 1999; 68: 2215-2219.

7. Imran Hamid U, Digney R, Soo L, Leung S, Graham AN. Incidence and outcome of re-entry injury in redo cardiac surgery: benefits of preoperative planning. Eur J Cardiothorac Surg 2015; 47: 819-823.

8. Cohn LH, Adams DH. Cardiac surgery in the adult. McGraw-Hill Education 2017.

9. Gasparovic H, Rybicki FJ, Millstine J, Unic D, Byrne JG, Yucel K, Mihaljevic T. Three dimensional computed tomographic imaging in planning the surgical approach for redo cardiac surgery after coronary revascularization. Eur J Cardiothorac Surg 2005; 28: 244-249.

10. Khan NU, Yonan N. Does preoperative computed tomography reduce the risks associated with re-do cardiac surgery? Interact Cardiovasc Thorac Surg 2009; 9: 119-123.

11. Sodian R, Schmauss D, Markert M, Weber S, Nikolaou K, Haeberle S, Vogt F, Vicol C, Lueth T, Reichart B, Schmitz C. Three-dimensional printing creates models for surgical planning of aortic valve replacement after previous coronary bypass grafting. Ann Thorac Surg 2008; 85: 2105-2108.

12. Jonas RA. Comprehensive Surgical Management of Congenital Heart Disease. $2^{\text {nd }}$ edition. CRC Press 2014. 